breathes and exudes knowledge of the field. The great merit of his book is to finally open a poorly studied field in Canadian history. His history of the CP is a provocative breath of fresh air in a field, which, for too long, was locked up in a dusty closet.

Serge Miville

York University

\title{
Francis Peddie, Young, Well-Educated, and Adaptable: Chilean Exiles in Ontario and Quebec, 1973 -2010 (Winnipeg: University of Manitoba Press, 2014). 208 pp. \$27.95 Paperback.
}

Historian Francis Peddie's monograph Young, Well-Educated and Adaptable: Chilean Exiles in Ontario and Quebec, 1973 -2010 (Winnipeg: University of Manitoba Press, 2014) asserts that in prolonged instances, the exiled will inevitably find "home" again, albeit a new one. Largely a qualitative study centred on the oral historical narratives of 21 Chilean forced migrants and two others intimately connected to the community through either activism and or other service provision, Peddie's analysis successfully intertwines the political, the national and social circumstances under which the 6,000 forced migrants that arrived between 1973-78 had an influential role "in establishing the collective identity of their national group in the country of refuge" (7). The largest cohort for more than a decade, Peddie argues that this group of forced migrants embody a distinct Chilean-Canadian identity; distinct from those Chilean migrants who came before and after them.

Peddie's work is unique from other scholars on this particular period of Chilean migration to Canada in that he rejects the influence of Edward Said and his conceptualisation "of exile as a permanent, untreatable wound" which "has influenced the discourse of academics, returnees, and exile groups," leaving little discussion room in the dominant narrative for other observers, such as himself, "who find evidence of positive, albeit unintended consequences of forced migration" (11). Subsequently, forty-years after their migration to Canada, due to distance in time and space from the country that fashioned their self-image, Peddie places an emphasis on the inevitable "metaphorical scar tissue for the wound of exile," as he argues that, his subjects are past the label of exile and transcend unitary identifiers (152-53). Life in Canada inescapably gives "rise to a new identity the chileno/a-and-something else: Canadian, Quebecois (e) Latin American, exile, immigrant, desexiliado, retornado, doctor, teacher, baker...." (152-153).

Admittedly a regional history, Peddie focuses on the lived experiences of Chilean migrants in the two distinct Canadian provinces of Ontario and Quebec, with a particular focus on the metropoles of Toronto and Montreal. Regional variances and commonalities in the lobby for migrants and the settle- 
ment process are addressed. However, due to logistical constraints, Peddie was unable to conduct interviews in other large Canadian Chilean epicenters such as Vancouver and Saskatoon, leaving his narrative unable to penetrate deeper into identifying any possibility of a pan-Canadian Chilean identity or variances. On the national level, Peddie effectively demonstrates how the controversial admission of people from the wrong side of the Cold War ideological divide had a lasting effect on Canadian immigration and refugee policy, establishing a precedent for the admission of political exiles over the decades that followed, including "the admission of left-wing Argentinians after 1976, as well as Salvadorians and Guatemalans fleeing right-wing regimes" $(3,154)$. Moreover, Peddie concisely addresses the height of the Canadian divide regarding the humanitarian Chilean crisis between September and November 1973, highlighting two formative occurrences "in the history of the Chilean exile community in Canada: the coup itself, and the establishment of a special program to assist in the resettlement of Chileans fleeing the military regime" (57-58).

Both by nature and by design, this book opens as transnational history, as all histories of migrations should. The proper geographical and historical contextualisation of this particular group's migration trajectory is the strongest element of his analysis. Peddie begins his study with an overview of the September 11, 1973 coup d'etat which precipitated the mass exodus of over 200,000 Chileans dispersed worldwide to escape the application of both direct and indirect repressive measures by Augusto Pinochet's military regime (5). By chronicling the domestic and foreign political forces at play in the removal of the left-leaning coalition parties collectively known as the Unidad Popular (Popular Unity; UP) under the leadership of President Salvadore Allende and tracing the rise of the military junta under Augusto Pinochet, Peddie effectively situates the Canadian political and social milieu under which Chilean forced migrants constructed an identity premised on political activism.

In this narrative, Peddie consciously uses the term 'forced migrants' versus 'refugees' to accurately characterize his subjects, due to the political and legal implications of the respective terms (8). Furthermore, Peddie's narrative of an exiled peoples with admirable agency and means forces the reader to reimagine steadfast archetypes of refugees that exist in Canadian society, as the exiles in this narrative buck the trend of representation as the poor downtrodden migrant seeking refuge in Canada. In fact, he surmises that many of the people from the exile wave that he interviews and examines display similar demographic and professional features which in the words of the Canadian Minister of Manpower and Immigration in 1973 made them "young, well-educated and adaptable people" (3). Peddie further argues that the exceptional skill set of the admitted group of migrants was not coincidental but rather a reflection of Canadian immigration policy at the time, as "the exiles were admitted to Canada because of their perceived ability to adapt and contribute to the economic and social life 